\title{
SCREENING OF FLUORESCENT PSEUDOMONADS BACTERIA ISOLATED FROM RHIZOSPHERES OF CULTIVATED AND WILD PLANTS IN VITRO FOR PLANT GROWTH PROMOTING TRAITS \\ Gamal-Eldin, H. ; M.Elbadry; S. Mahfouz and S.A.Abdelaziz \\ Department of Agricultural Microbiology, Faculty of Agriculture, Fayoum University, Fayoum, Egypt
}

\begin{abstract}
Utilization of fluorescent pseudomonads bacteria (FPB) as plant growth promoting agents offers a promising alternative solution to the application of potential harmful agrochemicals. In this study, FPB inhabiting ectorhizosphere and endorhizosphere of different cultivated and wild plants species were enumerated. Rhizospheres of wild plants, in general, were found to harbor high FPB population density compared to rhizospheres of cultivated plants. From counting plates, ninety five FPB isolates representing different morphological types were obtained. The isolates were in vitro screened for activities related to plant nutrition and plant growth regulation, for antifungal traits and for antagonistic potential towards different phytopathogenic fungi. Results showed that varied proportions of the FPB isolates are putative nitrogen fixers, solubilize phosphate and zinc, produce indoleacetic acid, produce varies antifungal traits and inhibit phytopathogenic fungi. Based on the results of screening, isolates were assessed for their ability to function as plant growth promoting rhizobacteria (PGPR) and ranked. Among the top 20 FPB isolates, 8 were isolated from rhizosphere of Rotrait (Zygophyllum coccineum), 6 from Kokia (Spergularia marina L.), 3 from Akol (Alhagi graecorum, boiss), and 3 from Maize (Zea mays L.) plant.

Keywords: fluorescent pseudomonads bacteria, cultivated and wild plants, ectorhizosphere and endorhizosphere, PGPR traits
\end{abstract}

\section{INTRODUCTION}

The estimated number of prokaryotic cells in our planet's soil is $2.6 \times 10^{29}$, providing an enormous capacity for diversity (Whitman et al., 1988) and a great potential for exploitation. The soil around the plant roots, the root surface and the root tissues are relatively rich in nutrients because as much as $40 \%$ of plant photosynthates are lost from the root regions support large microbial populations. One such population is free-living microorganisms which has been extensively investigated are "Rhizobacteria" which are the subset of rhizosphere bacteria known to aggressively colonize plant roots (Schroth and Hancock, 1982). Rhizobacteria have been shown to be efficient microbial competitors that can displace native root-colonizing microorganisms and persist throughout some or all of the crop season (Kloepper and Schroth, 1981). The general effects of rhizobacteria on host-plants range from deleterious to neutral or beneficial (Lavarovits and Nowak, 1997). Rhizobacteria that exert beneficial effects on plant development are termed "Plant Growth-Promoting Rhizobacteria" (PGPR) (Kloepper and Schroth, 1978) because their application is usually associated with increased rates of 
plants growth. PGPR promote plant growth and yield either directly or indirectly (Glick, 1995). The direct growth promoting mechanisms are as follows: i) nitrogen fixation, ii) solubilization of phosphate, iii) sequestering of iron by production of siderophores, iv) production of phytohormones such as auxins, cytokines, gibberellins; v) lowering of ethylene concentration (Glick et al., 1999). The indirect mechanisms of plant growth promotion by PGPR include i) antibiotic production, ii) depletion of iron from the rhizosphere, iii) synthesis of antifungal metabolites, iv) production of fungal cell wall lysing enzymes, v) competition for sites on roots vi) induce systemic resistance (Liu et al., 1995 ). Most PGPR consist of Gram negative genera, and the greatest number of strains are members of the fluorescent Pseudomonas spp. (Kloepper, 1993). Therefore, considerable research efforts are underway globally to exploit the potential of fluorescent pseudomonad bacteria (FPB) as PGPR inoculates, since they represent not only a dominant bacterial group in the rhizosphere ecosystem, but are also metabolically and functionally most versatile (Lugtenberg and Dekkers, 1999).

The main objective of this study was to find strains of fluorescent Pseudomonas spp. that have broad spectrum of plant growth-promoting traits and antagonistic potential against phytopathogenic fungi, that could be used as safe alternative for the overuse of harmful agrochemicals.

\section{MATERIALS AND METHODS}

\section{- Materials \\ Plants}

Five cultivated and five wild plant species were collected from different areas and fields in Fayoum Governorate, Egypt; the cultivated plants were Onion (Alium cepa L.), Maize (Zea mays L.), Sugar beet (Beta vulgaris L.), Tomato (Solanium lycopersicum L.), and Snap bean (Phasolius vulgaris L.), and the wild plants were: Homaid (Rumex vesicarius L.), Akol (Alhagi graecorum, boiss), Rotrait (Zygophyllum coccineum), Kokia (Spergularia marina L.) and Water hyacinth (Hyacinthus sp.).

\section{Fungal cultures}

Cultures of five soilborne pathogenic fungi, Pythium ultimum, Rhizoctonia solani, Fusarium oxysporum, Phytophthora infestans and Sclerotium cepivorum were kindly provided by the Plant Pathology Department, Faculty of Agriculture, Ain Shams University, Cairo, Egypt.

\section{- Methods}

\section{Plants collection}

For each plant species selected for isolation of root-associated fluorescent pseudomonas bacteria (FPB), roots of ten young and healthy plants were separated from shoots, shaken vigorously to remove loose soil, placed in sterile paper bags, and carried to the laboratory in an ice-box. In the laboratory, the ten roots belong to one plant species were pooled for an average sample. For each plant species, enumeration and isolation of FPB were conducted within 3 days of sampling. 


\section{Enumeration and isolation of root-associated fluorescent pseudomonad bacteria (FPB)}

Soil adhering to roots was removed and roots were subjected to gentle washing by sterile distilled water (SDW) until clear root surface was exposed and sufficient portion of roots were aseptically sliced into ca. $2 \mathrm{~cm}$ length segments. To enumerate and isolate the FPB inhabiting the surfacewashed roots, sets of fresh, washed root segments equivalent to $10 \mathrm{~g}$ dry weights were placed in sterile $250 \mathrm{ml}$ conical flasks and a solution of Tween phosphate buffered saline was added to give $100 \mathrm{ml}$ final volume. The flasks were shaken on rotary shaker at $500 \mathrm{rpm}$ for $10 \mathrm{~min}$. Ten fold serial dilutions were made in sterile $0.1 \mathrm{M} \mathrm{MgSO}_{4}(\mathrm{pH} 7.0)$, and $0.1 \mathrm{ml}$ aliquots from appropriate dilutions were spread-plated on King's medium B (KB) (King et al., 1954) plates supplemented with both penicillin (75000 unit $\left.\mathrm{I}^{-1}\right)$ and propylparahydroxylbenzoic acid $\left(0.5 \mathrm{~g} \mathrm{l}^{-1}\right)$ to avoid growth of $\mathrm{G}^{+}$bacteria and fungi, respectively. Two replicated plates were prepared from suitable dilutions and plates were incubated at $28^{\circ} \mathrm{C}$ for $48 \mathrm{~h}$ (Kremer et al., 1990).

To enumerate and isolate the FPB from the endorhizosphere, the surface-washed roots were aseptically sliced into $\mathrm{ca}$. $6 \mathrm{~cm}$ length segments which surface disinfected with $\mathrm{H}_{2} \mathrm{O}_{2}(10 \%, 15 \mathrm{sec})$, rinsed three times with SDW and dipping them in $1 \%$ sodium hypochlorite for $30 \mathrm{sec}$ followed by washing in SDW, dipping them again in $70 \%$ ethanol for $60 \mathrm{sec}$ followed by washing in several changes of SDW. Before disinfection, the two ends of root segments were sealed with paraffin wax to prevent the penetration of the disinfectants to interior root tissues. The surface sterility of the root segments was verified by spread-plating $0.1 \mathrm{ml}$ aliquot from SDW used in the last washing on nutrient agar plates which incubated at $30{ }^{\circ} \mathrm{C}$ for $72 \mathrm{~h}$, and if bacterial growth occurred, the sample was discarded. After cutting aseptically the two ends of root segments sealed with paraffin wax, portions equivalent to $10 \mathrm{~g}$ dry weight were mixed with small amounts of both sterile $0.1 \% \mathrm{M}$ $\mathrm{MgSO}_{4}(\mathrm{pH}$ 7.0) and washed, sterilized quartz sand, and macerated aseptically in sterile mortar (Kremer et al., 1990). The resulting slurry was homogenized and transferred to sterile $250 \mathrm{ml}$ conical flasks and a sterile 0.1 $\mathrm{M} \mathrm{MgSO}_{4}(\mathrm{pH} \mathrm{7.0)}$ solution was added to give $100 \mathrm{ml}$ final volume. Shaking, preparation of dilutions, and inoculation of KB plates were performed as described in case of the surface-washed roots. After incubation of inoculated plates for $48 \mathrm{~h}$, developed colonies which on exposure to UV-light $(\lambda=356$ $\mathrm{nm}$ ) exhibited fluorescence phenomenon were counted (Kremer et al., 1990). Colonies representing different morphological types were randomly selected, isolated, and further purified on KB plates. Isolates shown to be Gram negative rods and catalase and oxidase positive were designated as FPB with no further characterization attempted. In the present study, the FPB isolated from surface-washed roots (soil-free root surfaces) were designated as "Ectorhizosphere isolates", whereas those isolated from surfacedisinfected, macerated roots (interior root tissues) were designated as "Endorhizosphere isolates". 


\section{Screening FPB isolates for traits related to plant nutrition and growth stimulation}

$\mathrm{N}_{2}$-fixation was tested by growing them and an E. coli culture as control bacteria on plates of $\mathrm{N}$-free agar medium (Haahtela et al., $1983 \mathrm{a}, \mathrm{b}$ ) for $48 \mathrm{~h}$ at $28^{\circ} \mathrm{C}$. The isolates that grow after being sequentially transferred 10 times to the same medium were considered presumptive positive for $\mathrm{N}_{2}$ fixation (Cattelan et al., 1999). Phosphate and zinc solubilization was tested by the dissolution of precipitated tricalcium phosphate $\left[\mathrm{Ca}_{3}\left(\mathrm{PO}_{4}\right)_{2}\right]$ in an agar medium as described by Rodriguez et al., (2004). Zinc-solubilizing ability of the isolates was tested by the dissolution of precipitated zinc oxide $(\mathrm{ZnO})$ in an agar medium reported by Saravanan et al., (2003). A pinpoint inoculation of the bacterial isolates was made on surface dried plates. The plates were then incubated at $28^{\circ} \mathrm{C}$ for 7 days. Solubilization index ( $\left.\mathrm{SI}\right)$ was calculated according to the ratio of the total diameter (colony + halo zone) to the colony diameter (Edi-Premono et al., 1996). Indoleacetic acid (IAA) production was tested using the procedure described by Loper and Schroth, (1986) using KB medium supplemented with $\mathrm{L}$ - tryptophane $\left(2 \mathrm{mg} \mathrm{ml}^{-1}\right)$ and Salkowski's reagent. Development of a pink color indicates IAA production, and absorbance at $530 \mathrm{~nm}$ was recorded. The quantity of IAA was determined by comparison with a standard curve using IAA in the concentration range of 0 $15 \mu \mathrm{g} / \mathrm{ml}$. Antagonism towards phytopathogenic fungi (Fig. 1) was tested using five soilborne pathogenic fungi: Pythium ultimum, Rhizoctonia solani, Fusarium oxysporum, Phytophthora infestans and Sclerotium cepivorum in dual culture plate (Koch, 1997). Five $\mu \mathrm{l}$ of an exponentially growing bacterial culture was streaked along two opposite sides of surface-dried potato dextrose agar (PDA) plates. Plates subsequently incubated at $28^{\circ} \mathrm{C}$ for $24 \mathrm{~h}$. Following bacterial growth, mycelial agar plug of 5-mm-diameter from a 7day-old culture from the target fungi grown on PDA plate was placed in the center of the plate between the two parallel streaks of the test bacteria. Plates inoculated with target fungi alone served as control plates, and two replicate plates were used for each bacterial isolate. Plates were then incubated at $25^{\circ} \mathrm{C}$ for 7 days. Antagonistic activity was assessed by relating mycelial diameter on plates inoculated with bacteria to mycelial diameter on control plates and computing percentage growth inhibition (GI\%).

\section{Screening fluorescent pseudomonad isolates for antifungal triats}

Siderophores production was detected as described by Schwyn and Neilands, (1987) modified by (Palli, 2005). The assay was performed in 6-well plates and utilized the ternary complex chrome azurol S/ iron (III) / hexadecyltrimethylammonium bromide as an indicator. Change of the dye color from blue to orange was scored as positive for siderophores production. Hydrogen cyanide (HCN) production was detected by the method of Castric (1974) in which HCN was detected by color shift from yellow to orange in the filter paper strip saturated with alkaline picrate reagent .Chitinase production was assessed qualitatively by a microbiological method based on spoting of isolates on chitinase medium amended with colloidal chitin (Frändberg and Schnürer, 1998). Isolates exhibiting a transparent halo around the colony were considered positive for production of chitinase. Cellulase production was visualized by flooding the cellulose decomposition medium plates 
previously inoculated and incubated at $30 \mathrm{~min}$ for 8 days with $0.1 \%(\mathrm{w} / \mathrm{v})$ Congo red for 15 to 30 min followed by bleaching the plates with $1 \mathrm{M} \mathrm{NaCl}$, according to the method of Andro et al., (1984). Protease activity was indicated by casein degradation and formation of clearing zones in skim milk agar (Krechel et al., 2002). Salicylic acid (SA) production was assessed by the method of Leeman et al., (1996). Isolates were grown at $28^{\circ} \mathrm{C}$ for $48 \mathrm{~h}$ on a rotary shaker at $200 \mathrm{rpm}$ in flasks containing $25 \mathrm{ml}$ of the standard succinate medium (Meyer and Abdallah, 1987). Four $\mathrm{ml}$ of cell free culture filtrate was acidified with $1 \mathrm{~N} \mathrm{HCl}$ to $\mathrm{pH} 2$ and $\mathrm{SA}$ were extracted in $\mathrm{CHCl}_{3}$ by vigorously shake by hand for 30 seconds. After that, the tubes were centrifuged for $5 \mathrm{~min}$ at $3500 \mathrm{rpm}$. To the pooled $\mathrm{CHCl}_{3}$ phase, $4 \mathrm{ml}$ of distilled water and $5 \mu \mathrm{l}$ of $2 \mathrm{M} \mathrm{FeCl} l_{3} .6 \mathrm{H}_{2} \mathrm{O}$ were added. The absorbance of the purple iron-SA complex developed in the aqueous phase was measured at $527 \mathrm{~nm}$.

\section{RESULTS AND DISCUSSION}

In order to achieve the objective of this study, the fluorescent pseudomonad bacteria (FPB) were enumerated and isolated from ectorhizosphere (Ecto) and endorhizosphere (Endo) of different cultivated (CP) and wild plants (WP). The FPB isolates were in vitro screened for traits that might be associated with ability to function as PGPR.

Involvement of wild plants in this study is based on the speculate that wild plants are likely to harbor unique rhizobacterial populations that differ from those of cultivated plants which extensively bred and subjected to intensive applications of various agrochemicals (Elbeltagy et al., 2000 and Engelhand et al., 2000).In addition, the endophytic FPB inhabiting endorhizosphere were isolated in addition to FPB inhabiting ectorhizosphere. Endophytic bacteria have defined by Hallmann et al., (1997) as those bacteria that can be isolated from surface-disinfected plant tissues or extracted from within the plant and don't visibly harm the plant. It has been demonstrated that endophytic bacteria may have beneficial effects on host plants, such as growth promotion and biological control of pathogens (Sturz, et al., 2000).

\section{Enumeration and isolation of FPB}

Data presented in Table (1) shows that the FPB population density inhabiting rhizospheres of wild plants was higher and ranged from $3.5 \times 10^{3}$ to $22.5 \times 10^{3} \mathrm{CFU} \mathrm{g}^{-1}$ roots, compared to that of cultivated plants which ranged form $4.0 \times 10^{3}$ to $11 \times 10^{3} \mathrm{CFU} \mathrm{g}^{-1}$ roots. On the other hand, population density was considerably higher in ectorhizosphere than in the endorhizosphere, and FPB were not detected in endorhizosphere of seven plants species out of the ten tested. In addition, the effects of plant species and root microhabitat were obvious where roots of wild plants and ectorhizosphere harbored higher FPB population density compared with roots of cultivated plants and endorhizosphere, respectively. 
Table 1: Counts of fluorescent pseudomonas bacteria (FPB) associated with rhizospheres of different plant species and number of isolates obtained.

\begin{tabular}{|c|c|c|c|c|c|}
\hline \multirow[t]{2}{*}{ Plant species } & \multicolumn{2}{|c|}{$\begin{array}{c}\text { Count (CFU g g-1 dry } \\
\text { roots) }\end{array}$} & \multicolumn{2}{|c|}{ No. of isolates } & \multirow{2}{*}{$\begin{array}{c}\text { Total } \\
\text { isolates }\end{array}$} \\
\hline & Ecto & Endo & Ecto & Endo & \\
\hline \multicolumn{6}{|c|}{ (a) Cultivated plants } \\
\hline Onion(Alium cepa L.) & $4 \times 10^{3}$ & NCD & 3 & 0 & 3 \\
\hline Maize (Zea mays L.) & $1.1 \times 10^{4}$ & NCD & 9 & 0 & 9 \\
\hline Sugar beet (Beta vulgaris L.) & $8 \times 10^{3}$ & NCD & 6 & 0 & 6 \\
\hline Tomato(Solanium lycopersicum L.) & $4 \times 10^{3}$ & NCD & 3 & 1 & 4 \\
\hline Snap bean (Phasolius vulgaris L.) & $6 \times 10^{3}$ & $2 \times 10^{1}$ & 5 & 1 & 6 \\
\hline \multicolumn{6}{|c|}{$\begin{array}{ll}\text { (b) Wild plants } & \\
\end{array}$} \\
\hline Homaid (Rumex vesicarius L.) & $3.5 \times 10^{3}$ & NCD & 2 & 0 & 2 \\
\hline Akol (Alhagi graecorum, boiss) & $2.2 \times 10^{4}$ & $4.5 \times 10^{2}$ & 10 & 9 & 19 \\
\hline Rotrait (Zygophyllum coccineum) & $\begin{array}{l}1.35 \\
\times 10^{4} \\
\end{array}$ & NCD & 12 & 0 & 12 \\
\hline Kokia (Spergularia marina L.) & \begin{tabular}{|l|}
2.25 \\
$\times 10^{4}$ \\
\end{tabular} & $6 \times 10^{2}$ & 14 & 9 & 23 \\
\hline Water hyacinth (Hyacinthus sp.) & $1.8 \times 10^{4}$ & NCD & 11 & 0 & 11 \\
\hline Total & & & 75 & 20 & 95 \\
\hline NCD: No colonies detected & & & & & \\
\hline
\end{tabular}

Notable, was the observation that no FPB were detected in the endorhizosphere samples of 7 plant species out of the 10 tested. This may indicate that FPB did not colonize these endorhizosphere or FPB were present in much low numbers that counting method and /or medium used were not appropriate to recover them. Also, it must be taken into consideration that the lethal effect of the root surface disinfectants may extended to the interior root tissues and killed endophytic bacteria. However, it was reported that some plants are uncolonized by endophytic bacteria. The apparent absence of internal populations of bacteria was detected in $6 \%$ of alfalfa plants (Gagne et al., 1987), in $16 \%$ of pear trees (Whiteside and Spotts, 1991) and in 31\% to $49 \%$ of cotton plants (Misaghi and Donndelinger, 1990).

A total of 95 FPB were isolated, the lower proportion (29.5\%) was isolated from roots of cultivated plants and the higher proportion $(70.5 \%)$ was isolated from roots of wild plants. Taken into consideration that these isolates were taken from colonies representing different morphological types, the above finding may suggest that diversity of FPB inhabiting roots of the wild plants is much wider than that of FPB inhabiting roots of cultivated plants. Differences in numbers and composition of microorganisms in rhizospheres of different plant species and even different varieties within species have been reported. This may influenced by specific root exudates or other factors possibly controlled by specific genes in the plant (Kremer et al., 1990).

In this regard, Germida et al., (1998) found a more diverse flora of endophytic and rhizosphere isolates in oilseed rape than in wheat. Moreover, Hallmann et al., (1997) studied the endophytic bacteria of cotton and found that in some cases, individual cotton plants were colonized by only one or two 
species, while in other cases; up to 12 species of bacteria were recovered per plant.

\section{Screening FPB isolates for plant growth-promoting traits}

Although many studies have been conducted to identifying the specific traits by which PGPR promote plant growth, usually they were limited to studying just one or two of these traits (Cattelan et al., 1999). In the present work, the 95 FPB isolates were in vitro screened for a wide array of traits that might be associated with ability to function as PGPR.

\section{Screening FPB isolates for traits related to plant nutrition and plant growth regulation \\ Several Pseudomonas spp. have been reported to fix $\mathrm{N}_{2}$ (Cattelan et} al., 1999). Among the total 95 FPB isolates, (31.6\%) were found putative nitrogen fixers (PNF). The percentages of PNF isolates among cultivated plants, wild plants, ectorhizosphere and endorhizosphere isolates were $25.0 \%, 34.3 \%, 34.7 \%$ and $20.0 \%$, respectively (Table 2). However, testing for ability to reduce acetylene to ethylene should be preformed to confirm $\mathrm{N}_{2}$ fixation ability of these isolates.

In soil, both macro and micronutrients undergo a complex dynamic equilibrium of solubilization and insolubilization that is greatly influenced by the soil $\mathrm{pH}$ and microflora, and that ultimately affects their accessibility to plant roots for absorption (Saravanan et al., 2003)..

The FPB isolates were screened for their abilities to solubilize mineral phosphate $(P)$ and zinc $(Z n)$. The results presented in Table 2 revealed the following points:

1-Among the total 95 FPB isolates, $75(78.9 \%)$ and $57(60.0 \%)$ isolates found to have the ability to solubilize mineral $\mathrm{P}$ and $\mathrm{Zn}$, respectively.

2-The isolates varied in their abilities to solubilize $P$ and $\mathrm{Zn}$ as indicated by differences in solubilization index.

3-Proportions of WP and End isolates solubilizing $P$ were higher $(89.6 \%$ and $95.0 \%$, respectively) as compared with those of $\mathrm{CP}$ and Ecto isolates (53.6\% and $74.7 \%$, respectively).

4-On the other hand, proportions of CP, WP, Ecto and Endo isolates that able to solubilize $\mathrm{Zn}$ are approximately equal (about $60 \%$ ).

However, the occurrence and role of FPB able to solubilize mineral P and $\mathrm{Zn}$ in the endorhizosphere are questionable. 
Gamal-Eldin, H. et al.

T2 
Indoleacetic acid production

Indoleacetic acid (IAA) is one of the most physiologically active auxins. IAA is a common product of L-tryptophane metabolism by several microorganisms including PGPR (Arshad and Frankenberger, 1991). It is presumed that PGPR producing plant growth promoting agents play a critical role in plant growth promotion. It was found that inoculation of canola seeds with a PGPR isolate (Pseudomonas putida GR-122), which produces IAA resulted in 2-3 fold increases in the length of seedling roots (Caron et al., 1995). In the present work, the 95 FPB isolates were screened for their ability to produce IAA. Results presented in Table 2, show that $34.7 \%$ of the total 95 FPB isolates produced detectable levels of IAA in culture supernatants. These isolates varied greatly in their ability to produce IAA. Wild plant isolates showed very higher proportion (46.3\%) of IAA producers as compared with cultivated plant isolates (7.1\%). On the other hand, proportions of IAA producers were approximately equal in both ectorhizosphere and endorhizosphere isolates.

\section{Screening FPB isolates for antifungal traits}

The traits tested were production of siderophores (sid), salicylic acid (SA), hydrogen cyanide (HCN) and hydrolytic enzymes: cellulase, chitinase and protease, and the results are presented in Table 2. It was found that a 20 $\%$ of the total FPB isolates is able to produce Sid. The results also show that percentage of Sid -producers among WP (25.3\%), Endo isolates $(40.0 \%)$ was higher than that for $\mathrm{CP}(7.1 \%)$ and ectorhizosphere (Ecto) $(14.7 \%)$ isolates. It was reported that the ability of FPB to antagonize pathogenic fungi was related to the production of extracellular Sid which deprive phytopathogenic microflora of iron, thus limiting their growth (Leong, 1986 ). Also it was reported that plants use microbial Sid for iron acquisition ( Yehuda et al., 1996), and Sid is among factors involved in induced systematic resistance (ISR) (de Mayer and Höfte, 1997). The data showed that the ability to produce SA appears to be widespread among the FPB isolates .More than half of the 95 FPB isolates $(54,56.8 \%)$ were able to produce SA. The highest percentage of SA-producers $(70.0 \%)$ was recorded for both WP and Endo isolates, whereas the lowest one $(25.0 \%)$ was recorded for isolates of CP. Many studies indicated that SA plays an important role in plant defense response against pathogen attack and is essential for development of both systematic acquired resistance (SAR) and ISR in plants (van Loon et al., 1998 and Zang et al., 2002).

The results (Table 2) revealed that the proportion of $\mathrm{HCN}$-producers varied among the isolates of different plants species and rhizosphere microhabitats. Of the total 95 isolates, $34(35.8 \%)$ were able to produce $\mathrm{HCN}$ which ranking the second higher proportion after SA producers. The Ectoisolates showed the highest proportion $(41.3 \%)$ followed by WP isolates $(38.8 \%)$, whereas the lowest proportion was recorded for Endo-isolates $(15.0 \%)$. However, it was reported that cyanide production is an ambiguous trait and is sometimes associated with deleterious as well as beneficial rhizobacteria (Alström and Burns, 1989). Therefore, the high percentage of cyanogenic bacteria in the bacterial population of plant roots may possibly adversely affect plant growth, but may also inhibit the growth of fungal root 
pathogens. The results (Table 2) show that among the enzymes tested number of protease- producers is the highest $(29,30.5 \%)$ followed by cellulase-producers $(20,21.1 \%)$, whereas chitinase-producers recorded the lowest number $(8,8.4 \%)$. Compared to WP isolates, CP isolates showed high proportion of chitinase-producers. It is of interest that none of the total 20 Endo-isolates was able to produce chitinase, whereas among Ecto-isolates the proportion was $10.7 \%$. In vitro studies have demonstrated that the exposure of selected phytopathogenic fungi to lytic enzymes such chitinase, protease, gluconase or cellulase can result in degradation of the structural matrix of fungal cell wall (Dunne et al., 1998).

Screening FPB isolates for antagonism towards plant pathogenic fungi

Biological control of plant pathogens has been the focus of many studies in plant protection that search for alternative or complementary methods to the use of chemical pesticides. PGPR including FPB have captured the attention of many researchers because of the potential for developing these bacteria as inocula for plant disease control.

The 95 FPB isolates were in vitro screened for their ability to inhibit growth of five different soilborne plant pathogenic fungi: Pythium ultimum, Rhizoctonia solani, Fusarium oxysporum, Phytophthora infestans and Sclerotium cepivorum. Results presented in Table 2, show that $86(90.5 \%)$ of the 95 isolates screened were shown to exhibit a wide range of antagonistic activity against one or more of the five phytopathogenic fungi used in the screening. It was also observed that there are differences in proportion of $\mathrm{CP}$ and WP isolates that antagonize at least one of the 5 fungi tested which were $78.6 \%$ and $95.5 \%$, respectively.

Berg et al., (2002) found more bacterial isolates antagonistic to plantpathogenic fungi in the rhizosphere of strawberry than in the rhizosphere of oilseed rape and potato. In the present study, among the 75 Ecto and the 20 Endo isolates, $89.3 \%$ and $95.0 \%$, respectively were found to have antifungal activity. Chen et al., (1995) showed that of 170 bacterial strains isolated from internal tissues of cotton, $40(23.5 \%)$ possessed biological control against Rhizoctonia solani in cotton, and 25 (14.7\%) induced systemic resistance to Colletotrichum orbiculare in cucumber. In the present work, of the 86 isolates showed antifungal activity, 46 (53.5\%), 74 (86.0\%), 75 (87.2\%), 79 (91.9\%) and $79(91.9 \%)$ were antagonistic against $P$. ultimum, $R$. solani, $F$. oxysporum, $P$. infestans or $S$. cepivorum, respectively.

Regarding the antagonistic spectrum of the antagonistic FPB isolates (Table 2), antagonistic isolates of WP showed broader spectrum as compared with antagonistic isolates of $\mathrm{CP}$ where $57.8 \%$ and $22.7 \%$, respectively were found to antagonize all the five fungi used. The proportions were $46.3 \%$ and $57.9 \%$ among antagonistic isolates of Ecto and Endo, respectively.

On the basis of the results obtained, FPB isolates belonging to WP or Endo seem to be highly efficient against fungal pathogens tested as compared to $\mathrm{CP}$ or Ecto isolates. It was reported that the plant species or cultivar and especially the composition of root exudates plays a key role in the diversity of rhizobacterial populations colonizing the roots (Siciliana et al., 
1998) and can influence the frequency of antagonistic bacteria (Berg et al., 2000).

Assessment of the FPB isolates according to their in vitro plant growthpromoting traits

In an attempt to better select FPB isolates with high plant growth promotion potential, and to compare the potential of the FPB isolates from different plant species and two different rhizosphere microhabitats, a bonitur scale similar to that described by Krechel et al., (2002) was generated ( Fig. 2) and used for assessment of FPB isolates. In this scale, points were given to each bacterial trait in vitro determined within this study. Up to three points each were given for antagonistic activity towards each of the five indicator fungi, one point for each of the three hydrolytic enzymes, HCN and PNF, three points for phosphate solubilization, and IAA production, and two points for zinc solubilization. Siderophores were given two points, one as antifungal trait and one for their use by plants for iron acquisition. The point given to $\mathrm{HCN}$ production was included in the assessment points of antifungal traits, whereas excluded from the sum assessment points because HCN can adversely affect plant growth. This generated a bonitur scale of 32 points.

Results of the assessment revealed the following points:

- For all the 95 FPB isolates, $\Sigma$ assessment values varied between 1 point and 27 points.

- Isolates of the wild plant Rotrait showed the highest $\Sigma$ assessment values ranged from 17 to 27 points, while the lowest values (1 to 5 points) were for FPB isolated from roots of onion plants.

- Compared with isolates of wild plants and ectorhizosphere, cultivated plants and endorhizosphere isolates showed lower $\Sigma$ assessment values. This mainly caused by low or no antifungal activity and /or absence of lytic enzymes. 
Gamal-Eldin, H. et al.

T3 
J. Agric. Sci. Mansoura Univ., 33(5), May, 2008
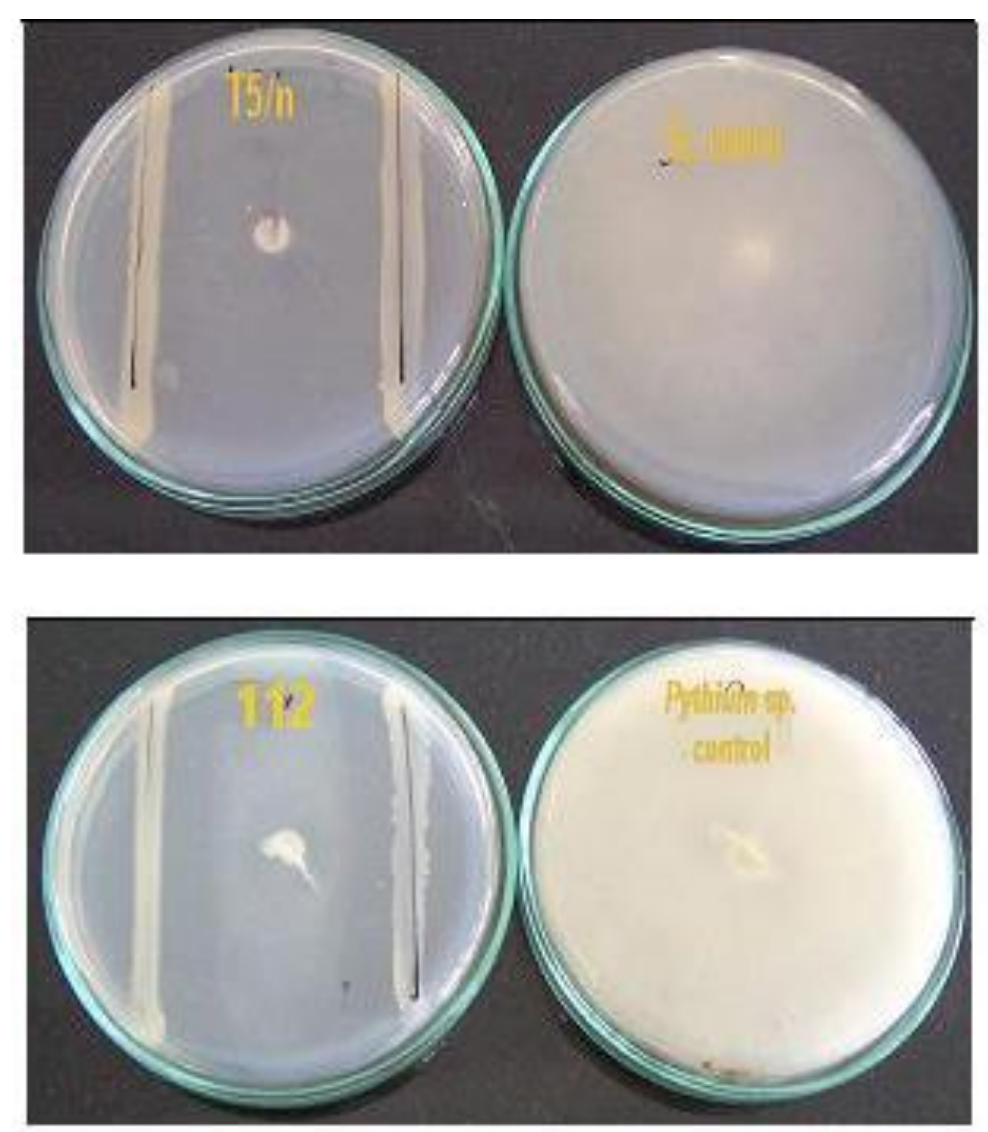

(A)

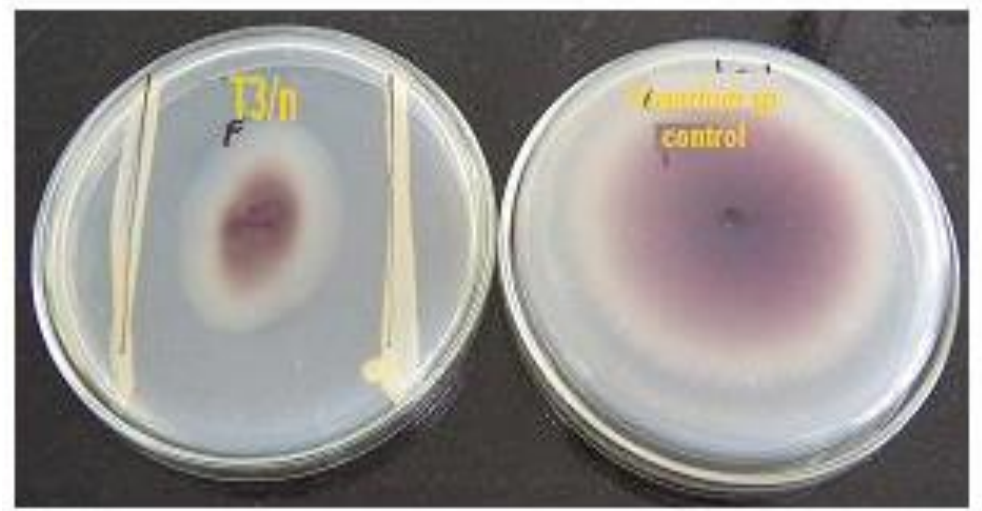

(B)

\section{(C)}

Fig.1: Dual assay plates showing antifungal activity of FPB isolates against $S$. cepivorum (A) $P$. Infestans (B) and $F$. oxysporum (C). 
Gamal-Eldin, H. et al.

Fig. 2: A bonitur scale of 32 points used for assessment the FPB isolates based on their results in vitro screening for PGPR traits. 
- Based on the $\Sigma$ assessment values of all the 95 FPB isolates, the top 20 isolates and their traits are listed in Table 3 . It is of interest that among those 20 isolates, 17 (85\%) were isolated from WP roots, and the remaining $3(15 \%)$ were isolated from roots of the cultivated maize plants. Regarding rhizosphere microhabitats, numbers of Ecto-isolates was the higher (17, $85 \%)$ compared to Endo-isolates (3, $15 \%)$.

Collectively, the results suggest that compared with cultivated plants, rhizospheres of wild plants are very good source for FPB with multiple plant growth promoting traits.. Moreover, FPB inhabiting rhizospheres of wild plants showed higher density, wider diversity, and higher proportion of isolates possess high number of PGP traits with high values, and higher proportion of antifungal isolates with broader antifungal spectrum. Taking into consideration that the presence of plant growth promoting traits in vitro does not guarantee that a particular isolate is a PGPR, further studies on the performance of these isolates in vivo are needed to uncover their efficacy as effective plant growth promoting rhizobacteria.

\section{REFERENCES}

Alström, S. and Burns, R. G. (1989). Cyanide production by rhizobacteria as a possible mechanism of plant growth Inhibition.Biology and Fertility of Soils 7,232-238.

Andro,T.; Chambost,J.P.; Kotoujansky,A.; Cattaneo,J.; Bertheau,Y.; Barras,F.; van Gijsegem,F. and Coleno,A. (1984). Mutants of Erwinia chrysanthemi defective in secretion of pectinase and cellulase. Journal of Bacteriology 160, 1199-1203.

Arshad, M. and Frankenberger, W.T. Jr. (1991). Microbial production of plant hormones. Plant and Soil 133, 1-8.

Barzilian Journal of Microbiology 34, 121-125.

Berg, G.; Kurze, S.; Buchner, A.; Wellington, E. M. and Smalla, K. (2000). Successful strategy for the selection of new strawberry-associated rhizobacteria antagonistic to Verticillium wilt. Canadian Journal of Microbiology 46, 1128-1137.

Berg, G.; Roskot, N.; Steidle, A.; Eberl, L.; Zock, A. and Smalla, K. (2002). Plant-dependent genotypic and phenotypic diversity of antagonistic rhizobacteria isolated from different Verticillium host plants.Applied and Environmental Microbiology 68,3328-3338.

Caron, M.; Patten, C.; Ghosh, S. and Glick, B.R. (1995). Effect of the plant growth promoting rhizobacterium Pseudomonas putida GR12-2 on the physiology of canola roots. In proceedings of Twenty-Second Annual Meeting of Plant Growth Regulation Society of America, Green, D.W. (ed.), July 18-20, pp. 279-302.

Castric,P.A.(1974). Hydrogen cyanide, a secondary metabolite of Pseudomonas aeruginosa. Canadian Journal of Microbiology 21,613618. 
Cattelan, A.J.; Hartel, P.G. and Fuhramnn, J.J. (1999). Screening for plant growth-promoting to promote early soybean growth. Soil Science Society of America Journal 63, 1670-1680.

Chen, C.; Bauske, E. M.; Musson, G.; Rodriguez-Ka'bana, R.; and Kloepper, J. W. (1995). Biological control of Fusarium wilt on cotton by use of endophytic bacteria. Biological Control 5, 83-91.

De Mayer,G. and Höfte,M (1997). Salicylic Acid Produced by the rhizobacterium Pseudomonas aeruginosa 7NSK2 induces resistance to leaf Infection by Botrytis cinerea on bean. Phytopathology 86,588-593.

Dunne, C.; Moënne-Loccoz, Y.; McCarthy, J.; Higgins, P.; Powell, J.; Dowling, D. N. and O'Gara, F. (1998). Combining proteolytic and phloroglucinol-producing bacteria for improved biocontrol of Pythiummediated damping-off of sugar beet. Plant Pathology 47, 299-307.

Edi-Premona, M.; Moawad, A.M. and Vlek, P.L.G. (1996). Effect of phosphate-solubilizing Pseudomonas Putida on growth of maize and its survival in the rhizosphere. Indonesian Journal of Crop Science 11, 1323.

Elbeltagy,A.; Nishioka, K.; Suzuki, H.; Sato,T.; Sato, Y.; Moriaski, H., Mitsui, $\mathrm{H}$. and Minamisawa, K. (2000). Isolation and characterization of endophytic bacteria from wild and traditionally cultivated rice varieties. Soil Science and Plant Nutrition 46,617- 629.

Engelhand, M.; Hurek, T. and Reinhold-Hurek, B. (2000).Environmental Microbiology 2, 131-141

Frändberg, E. and Schnürer, J. (1998). Antifungal activity of chitinolytic bacteria isolated from airtight stored cereal grain.Canadian Journal of Microbiology 44, 121-127

Gagne, S.; Richard, C.; Rousseau, H., and Antoun, H. (1987). Xylem-residing bacteria alfalfa roots. Canadian Journal of Microbiology 33, 996-1000.

Germida, J.J.; Sicilliano, S.D.; de Freitas, J.R. and Seib, A.M. (1998). Diversity of root-associated bacteria associated with field-grown canola (Brassica napus L.) and wheat (Triticum aestivum L.). FEMS Microbiology Ecology 26, 43-49.

Glick, B. R.; Patten, C. L.; Holguin, G. and Penrose, D. M. (1999). Biochemical and genetic mechanisms used by plant growth-promoting bacteria. Imperial College Press. London, 267p.

Glick, B.R. (1995) . The enhancement of plant growth by free-bacteria. Canadian Journal of Microbiology 41,109-117.

Haahtela, K.; Helander, I; Nurmiaha- Lassila, E.L. and Sundman, V. (1983a). Morphological and physiological characteristics and lipopolysaccharidecomposition of $\mathrm{N}_{2}$-fixing $\left(\mathrm{C}_{2} \mathrm{H}_{2}\right.$-reducing $)$ rootassociated Pseudomonas sp. Canadian Journal of Microbiology 29, 874-880.

Haahtela, K.; Kari, K., and Sundman, V. (1983b). Nitrogenase activity (Acetylene Reduction) of root-associated, cold-climate Azosperillum, Enterobacter, Klabsilla, and Pseudomonas species. Applied and Environmental Microbiology 45,563-570. 
Hallmann, J., Quatt-Hallmann, A.; Mahaffee; W.F.; and Kleopper, J.W. (1997). Bacterial endophytes in agricultural crops. Canadian Journal of Microbiology 43, 895-914.

King, E.O.; Ward, M.K. and Raney, D.E. (1954). Two simple media for the demonstration of pyocyanin and fluorescin. Journal of Laboratory and Clinical Medicine 44,301-307.

Kloepper, J. W. (1993). Plant growth-promoting rhizobacteria as biological control agents. In: Soil Microbial Ecology: Applications in Agricultural and Environmental Management, F. B. Metting, Jr., ed. Marcel Dekker Inc., New York,. pp. 255-274.

Kloepper, J.W. and Schroth, M.N. (1978) . Plant growth promoting rhizobacteria on radishes. In: Proceedings of the $\mathrm{IV}^{\text {th }}$ International Conference on Plant Pathogenic Bacteria, Station de Pathologie Végétable et Phytobactériologie INRA. Angers, France Vol.2, pp. 879882.

Kloepper, J.W. and Schroth, M.N. (1981). Relationship of in vitro antibiosis of plant growth promoting rhizobacteria on potato plant development and yield. Phytopathology 70, 1078-1082.

Koch, E. (1997). Screening of rhizobacteria for antagonistic activity against Pythium ultimum on cucumber and kale. Journal of Plant Diseases and Protection 104, 353-361.

Krechel, A.; Faupel, A.; Hallmann, J.; Ulrich,A. and Berg,G. (2002). Potatoassociated bacteria and their antagonistic potential towards plantpathogenic fungi and the plant-parasitic nematode Meloidogyne incognita (Kofoid and White) Chitwood. Canadian Journal of Microbiology 48,772-786.

Kremer, R. J.; Begonia, M.F.T.; Stanley, L. and Lanham, E.T. (1990). Characterization of rhizobacteria associated with weed seedlings. Applied and Environmental Microbiology 56, 1649-1655.

Lazarovits, G. and Nowak, J. (1997). Rhizobacteria for improvement of plant growth and establishment. Hort Science 32, 188 -192.

Leeman, M.; Denouden, F. M. ;van Pelt, J. A. ; Cornelissen, C.; Matamala Garros, A. ;Bakker, P. A. H. M. and Schippers, B. (1996). Suppression of Fusarium wilt of radish by co-inoculation of fluorescent Pseudomonas spp. and root-colonizing fungi. European Journal of Plant Pathology 102, 21-31.

Leong, J. (1986). Siderophores: their biochemistry and possible role in the biocontrol of plant pathogens. Annual Review of Phytopathology 26, 187-209.

Liu, L.; Kloepper, J. W. and Tuzun, S. (1995). Induction of systemic resistance in cucumber by plant growth-promoting rhizobacteria: Duration of protection and effect of host resistance on protection and root colonization. Phytopathology 85, 1064-1068.

Loper, J.E. and Schroth, M.N. (1986). Influence of bacterial sources of indole3 -acetic acid on root elongation of sugar beet. Phytopathology 76, 386389.

Lugtenberg B. J. J. and Dekkers L. C. (1999). What makes Pseudomonas bacteria rhizosphere competent? Environmental Microbiology 1, 9-13. 


\section{Gamal-Eldin, $\boldsymbol{H}$. et al.}

Meyer, J.M. and Abdallah, M.A. (1987). The fluorescent pigment of Pseudomonas fluorescens : biosynthesis, purification and physicochemical properties. Journal of General Microbiology 107,319 328.

Misaghi, I.J. and Donndelinger. C.R. (1990). Endophytic bacteria in symptomfree cotton plants. Phytopathology 80,808-811. Antonie van Leeuwenhoek 81,599-606.

Pallai, R. (2005). Effect of plant growth-promoting rhizobacteria on canola (Brassica napus. L) and lentil (Lens culinaris. Medik) plants. Thesis, Master of Science, Department of Applied Microbiology and Food Science, University of Saskatchewan, Saskatoon.Canada.

Preferential occurrence of diazotrophic endophytes, Azoarcus spp., in wild rice species and land races of Oryza sativa in comparison with modern races.

Rodriguez, H.; Gonzalez, T.; Igoire, I. and Bashan, Y. (2004). Gluconic acid production and phosphate solubilization by the plant growth promoting bacterium Azospirillum spp. Naturwissneschaften 91, 552-555.

Saravanan, V.S.; Subramoniam, S.R. and Raj, S.A. (2003). Assessing in vitro solubilization potential of different zinc solubilizing bacterial (ZSB) isolates.

Schroth, M. N. and Hancock, J. G.(1982). Disease-suppressive soil and rootcolonizing bacteria. Science 216,1376-1381

Schwyn, B. and Neilands, J.B. (1987). Universal chemical assay for detection and determination of siderophores. Analytical Biochemistry 160, 47- 56.

Siciliano S.D.; Theoret C.M.; de Freitas J.R.; Hucl P.J. and Germida, J.J. (1998). Differences in the microbial communities associated with the roots of different cultivars of canola and wheat. Canadian Journal of Microbiology 44, 844-851.

Sturz, A. V.; Christie, B. R. and Nowak, J. (2000). Bacterial endophytes: Potential role in developing sustainable systems of crop production. Critical Reviews in Plant Sciences 19, 1-30

van Loon, L.C.; Bakker, P.A.H.M. and Pieterse, C.M.J. (1998). Systemic Resistance Induced by rhizosphere bacteria. Annual Review of Phytopathology 36, 453-483.

Whitesides, S.K. and Spotts, R.A. (1991). Frequency, distribution, and characterization of endophytic Pseudomonas syringe in pear trees. Phytopathology 81,453-457.

Whitman, W. B. ; Coleman, D. C. and William J. W. (1988). Prokaryotes: The unseen majority. Proceedings of the National Academy of Sciences 95, 6578-6583.

Yehuda, Z.; Shenker, M., Romheld, V., Marschner, H., Hadar, Y. and Chen, Y. (1996). The role of legend exchange in the Uptake of Iron from microbial siderophores by gramineous plants. Plant Physiology 112, 1273-1280.

Zhang, S.; Moyne, A.L.; Reddy, M.S. and Kloepper, J.W. (2002). The role of salicylic acid in induced systemic resistance elicited by plant growthpromoting rhizobacteria against blue mold of tobacco. Biological Control 25, 288-296. 


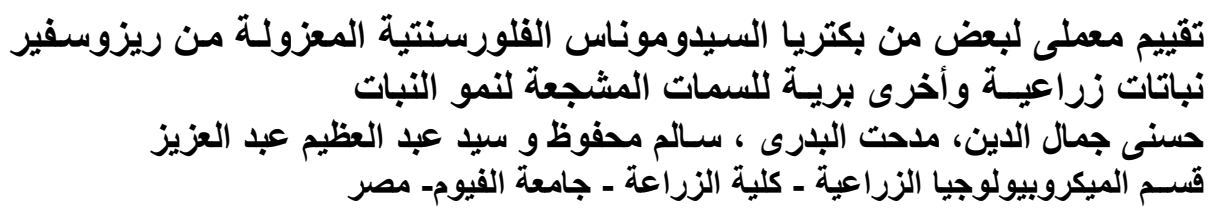

هدف هذا البحث هو الحصول على عزلات من بكتريا السيدوموناس الفلور سنتية (FPB) تتميز

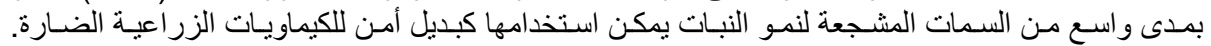

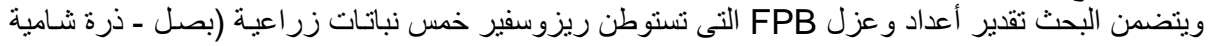

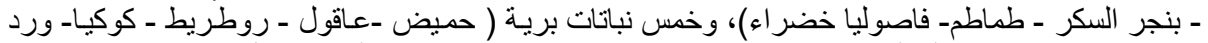

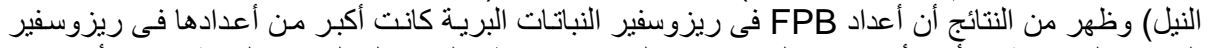

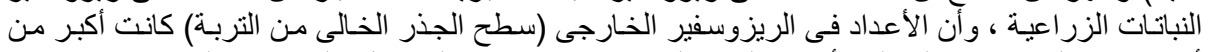

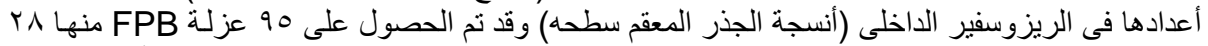

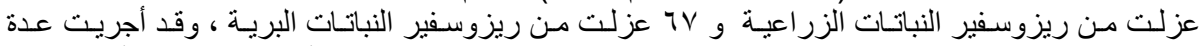

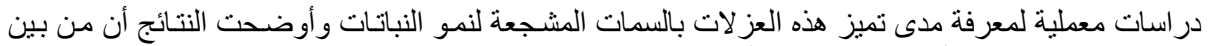

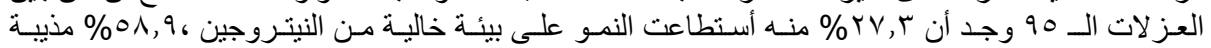

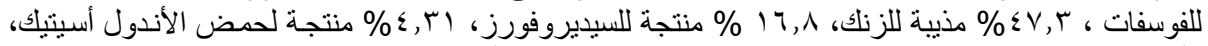

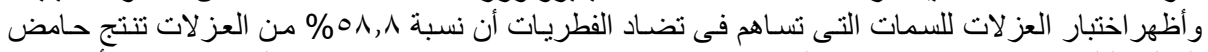

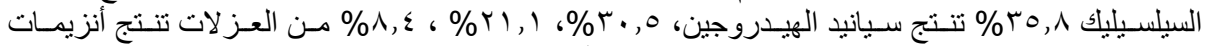

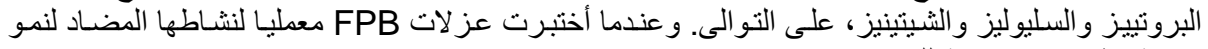
خمسة فطريات ممرضة للنبات وهى:

Pythium ultimum, Rhizoctonia solani, Fusarium oxysporum, Phytophthora infestans and Sclerotium cepivorum

أظهرت النتائج أن ه . 9 \% من العز لات أظهرت تضاد لفطر واحد على الأقل من بين الفطريات

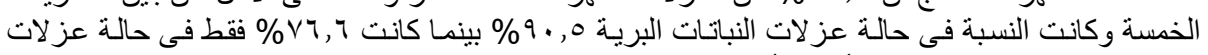

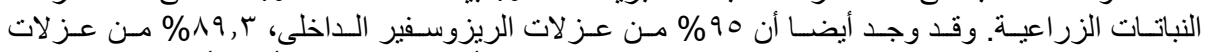

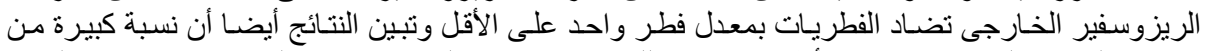

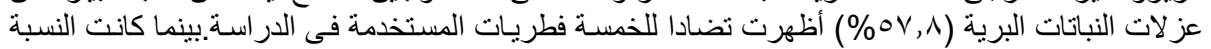

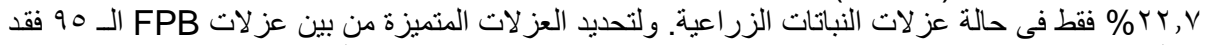

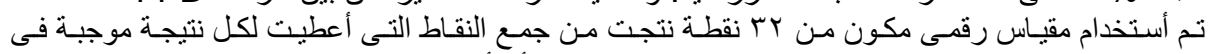

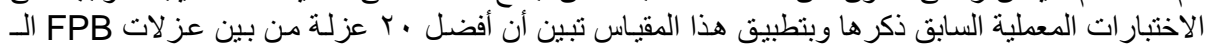

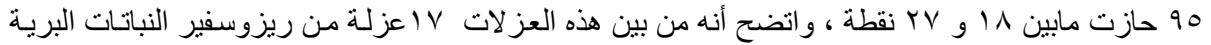

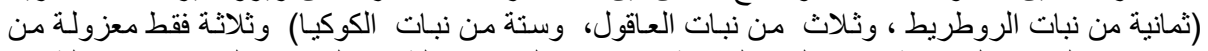

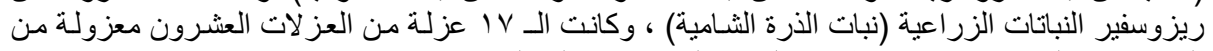

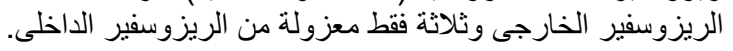

